\title{
Expression of CD38 and CXCR3 in children with atopic dermatitis.
}

\author{
Fawzia A. EL.Sheshtawy, Naglaa A .Ahmad , Manal Abdul Salam \\ Departments of Clinical Pathology, Dermatology , Pediatric \# , Faculty of \\ Medicine for Girls- Al Azhar University
}

\section{Abstract}

Background : Atopic dermatitis ( AD) is a chronic or chronically relapsing inflammatory skin disease with a prevalence ranging from $10 \%$ to $20 \%$ in children of developed countries. Skin-infiltrating leukocytes play a pivotal role in the initiation and amplification of atopic skin inflammation. The cytokines produced by $\mathrm{T}$ helper- 2 ( Th2) cells are crucial factors in the induction and maintenance of the disease .

Aim: to study the percentage of expression and mean fluorescence intensity( MFI) of the activation marker CD38 and the chemokine receptor CXCR3 on peripheral blood CD3+ lymphocytes in children with atopic dermatitis . Also total serum IgE and absolute differential count were evaluated .This might be targets for therapy in disease .

Methods: This study was conducted on thirty cases of AD children. Their age range was 3- 10 years. Also non atopic fifteen children age and sex matched with disease group were included as a control group. The percentage of expression of the CD38, CXCR3 and MFI were analyzed by flow- cytometry on peripheral blood CD3+ T lymphocytes . Also total serum $\mathrm{IgE}$ levels was measured by immunonephelometry. The absolute eosinophil , absolute lymphocytes, absolute neutrophil count were evaluated .

Results: The mean percentage of CD38 expression on CD3 + lymphocytes and MFI were $70.5 \%$ and 5.8 respectively in AD children compared with $17.8 \%$ and 5.1 in non -atopic children healthy control $(\mathrm{p}<0.01$ and $\mathrm{p}>0.05$ respectively $)$. The mean percentage of CXCR3 expression on CD3+ T lymphocytes and MFI in AD children were $17.9 \%$ and 2.9 respectively compared with $67.93 \%$ and 3.3 in healthy controls $(p<0.01$ and $p>0.05$ respectively ). The mean of the total serum IgE in the patient group was $199.3 \mathrm{IU} / \mathrm{ml}$ compared with $62.27 \mathrm{IU} / \mathrm{ml}$ in non-atopic children $(\mathrm{p}<0.01)$.

Conclusion : These results suggest that there is a relation between atopic conditions and an increase in peripheral blood T lymphocyte expressing CD38\% and decrease expression of CXCR3\%.The presence of high expression of CD38 in atopic patients seems to confirm the role of this molecule as an activation marker useful for evaluation of Th2 immune response . whereas CXCR3-expression on CD3+ lymphocytes decreased in AD than normal control as the chemokine receptor profile determine the migratory patterns of leukocytes. These results may suggest the dysbalance between Th1/ Th2 in AD patients .

Key words : CD 38 , CXCR3, Flow- Cytometry, AD .

\section{Introduction}

Atopic dermatitis (AD) is a common dermatologic condition that is characterized by pruritic and eczematous lesions persisting chronically. As an immunologic aspect of $\mathrm{AD}$, there are several reports that suggest a Th1/Th2 imbalance (i.e., an uneven proportion of Th1 and Th2 immune cells) in AD. This imbalance favors Th2, and high serum IgE levels as well as blood eosinophilia, which are all characteristics of $\mathrm{AD}$. High serum IgE and eosinophil are provoked by Th2 cytokines, interleukin- 4 (IL-4), IL-5, and IL-13. (.1-2 ).
CD38 is a glycoprotein found on the surface of many immune cells (white blood cells), including $\mathrm{CD} 4+, \mathrm{CD} 8+, \mathrm{B}$ and natural killer cells. It is a marker of cell activation.It is a multi-functional ectoenzyme capable of catalysing multiple reactions (ADP-ribosylcyclase, NADglycohydrolase, cADP-ribosyl cyclase) and generating products involved in calcium signalling (4). Furthermore, CD38 is an adhesion molecule. It is hypothesized that the interaction between CD38 and the corresponding counter-receptor CD31 
mediates a weak adhesion between lymphocytes and endothelial cells during the process of lymphocyte homing (5) . Perhaps the most complex biological feature of CD38 is its role as a signalling molecule. It has been shown that CD38 delivers activation signals in $\mathrm{T}$ and $\mathrm{B}$ lymphocytes as well as NK cells and monocytes, resulting in cytokine synthesis and secretion as well as in activation of several secondary messengers. It has been hypothesized that CD38 interacts directly with $\mathrm{T}$ cell receptors (TCR) and $\mathrm{B}$ cell receptors (BCR) in delivering activation signals to the corresponding cells (6) .

Chemokine receptor CXCR3 is a $\mathrm{G}_{\mathrm{i}}$ protein-coupled receptor in the CXC chemokine receptor family. Other names for CXCR3 are $\mathrm{G}$ protein-coupled receptor 9 (GPR9) and CD183 ( 8 ).

CXCR3 is expressed primarily on activated T lymphocytes and NK cells, ( 9 ) some epithelial cells and some endothelial cells. CXCR3 and CCR5 are preferentially expressed on Th1 cells, CXCR3 is able to regulate leukocyte trafficking. Binding of chemokines to CXCR3 induces various cellular responses, most notably integrin activation, cytoskeletal changes and chemotactic migration. CXCR3-ligand interaction attracts Th1 cells and promotes Th1 cell maturation (9) .

\section{Subjects and methods}

This study was carried out on 30 atopic dermatitis children 15 males and 15 females, their ages ranged between 3-10 years (mean 6.5) selected from the outpatient clinics of Dermatology Department of Al-zahraa Hospital Al- Azhar University Faculty of Medicine for Girls .

Fifteen apparently healthy children matching the age and gender of the patients served as a control group. They were 9 males and 6 females (age ranged from $4-$ 6 years with mean 5.0 years ). They had no dermatologic or systemic diseases, no parasitic infestation or history of atopic conditions.

Atopic dermatitis was defined according to the UK AD diagnostic criteria, which are both specific and sensitive. $(2,3)$ These criteria are as follows: an itchy skin condition plus three of more of the following: onset below 2 years of age; history of skin crease involvement; history of generally dry skin; visible flexural dermatitis; personal history of another atopic disease (or history of atopic disease in a first degree relative) .

$5 \mathrm{ml}$ of peripheral venous blood were withdrawn ; under aseptic condition, from each subject and control .They were divided as follows :

A- $3 \mathrm{ml}$ anticoagulated with EDTA for complete blood picture, differential leucocyte count and flow cytometric analysis .

B- $2 \mathrm{ml}$ without anticoagulant for serum IgE level

Complete blood count was done by automated cell counter model Sysmex Kx N 21 and blood films were stained by Leichman,s stain .

- Quantitative total IgE was done by nephlometer model BN. The Kits was supplied by Dad Behring ( Catalog No DE 19714 U.S .A)

The polystyrene particles coated with antibodies specific to human $\operatorname{IgE}$ were aggregated when mixed with serum sample containing human $\operatorname{IgE}$. These aggregates scatter a beam of light passed through the sample. The intensity of the scattered light was proportional to the concentration of the relevant protein in the sample. The result was evaluated by the comparison with a standard of known concentration .

\section{- CD38 - PE and CXCR3- PE detection by flow cytometry model BECKMAN COULTER MACHINE :}

\section{Preparation of surface CD 38 and CXCR3 analysis :}

Two tubes for each sample were used, in the first one $50 \mathrm{ul}$ of diluted blood by phosphate buffer saline (PBS) was added to $5 \mathrm{ul}$ of the monoclonal antibody (antihuman CD38 PE conjugated) and 5ul CD3 FITC . In the second Tube also $50 \mathrm{ul}$ of PBS diluted blood was added to $5 \mathrm{ul}$ of the monoclonal antibody (antihuman CXCR3 PE) and 5ul CD3 FITC Conjugated.

All Kits supplied by( BECKMAN COULTER) ( Catalog No B.P177-13276 Marseille Cedex 9 France). The tubes vortexed and then incubated in the dark at room temperature for $15 \mathrm{~min} .1 .5 \mathrm{ml}$ of lyse 
solution (NH4cl buffered with $\mathrm{KHCO} 3$ at $\mathrm{PH}$ 7.2), was added and then vortexed. The sample was then ready for flow cytometer processing .

\section{Statistical Analysis:}

Data was analyzed by Microsoft Office 2003 (excel) and Statistical Package for Social Science (SPSS) version 10.

Parametric data was expressed as mean $\pm \mathrm{SD}$, and non parametric data was expressed as number and percentage of the total.

Measuring the mutual correspondence between two values was done using the Spearman correlation coefficient.

\section{Results}

Comparison between AD children and control group showed high significant elevation of absolute eosinophil ,platelet and total $\mathrm{IgE}$ in $\mathrm{AD}$ patients when compared with control group. Age revealed significant elevation in $\mathrm{AD}$ in comparison with control . High significance decrease in $\mathrm{Hb}$ level in $\mathrm{AD}$ patient when compared to control was detected. TLC, absolute lymphocytes and absolute neutrophil showed no significant difference.

Highly significant increase in \% of expression of CD38 on CD3+ lymphocytes was detected in $\mathrm{AD}$ children when compared with the control group. On the other hand \% of expression of CXCR3 on CD3+ lymphocytes showed high significant reduction in $\mathrm{AD}$ group in comparison with the control group. No significance difference in MFI between patients and control group .

A highly significant positive correlation were detected between percentage of expression of $\mathrm{CD} 38$ on $\mathrm{CD} 3+$ lymphocytes and absolute eosinophils . A highly significant negative correlation was found between CD38 \% and age. Also a significance positive correlation was detected between CD38\% and total serum IgE level .

Table (1): Comparison between AD children and control group as regard age , TLC, absolute eosinophils , absolute lymphocytes, absolute neutrophils ,Hb ,platelets, and total IgE.

\begin{tabular}{|c|c|c|c|c|c|c|c|}
\hline \multirow[b]{2}{*}{ Parameter } & \multicolumn{2}{|c|}{ Patients (n) 30} & \multicolumn{2}{|c|}{ Controls (n) 15} & \multirow[b]{2}{*}{$\mathbf{t}$} & \multirow[b]{2}{*}{$\begin{array}{c}\mathrm{P}- \\
\text { value }\end{array}$} & \multirow[t]{2}{*}{ Sig. } \\
\hline & Mean & \pm SD & Mean = & \pm SD & & & \\
\hline Age /years & 6.500 & $\pm \quad 2.240$ & $5.700=$ & \pm 0.926 & 2.478 & 0.017 & NS \\
\hline TLCx $10^{9} / 1$ & 10.277 & $\pm \quad 2.940$ & $8.680=$ & \pm 1.903 & 1.907 & 0.063 & NS \\
\hline $\begin{array}{c}\text { Absolute Eosinophil } \\
\times 10^{9} / 1\end{array}$ & 1023.000 & $\pm \quad 397.676$ & $280.400=$ & \pm 57.937 & 7.154 & 0.000 & $\mathrm{HS}$ \\
\hline $\begin{array}{c}\text { Absolute Lymphocyte } \\
\times 10^{9} / 1 \\
\end{array}$ & $4303.033 \pm$ & $\pm \quad 1497.729$ & $3847.333=$ & \pm 1054.599 & 1.052 & 0.298 & NS \\
\hline $\begin{array}{c}\text { Absolute Neutrophil } \\
\times 10^{9} / 1\end{array}$ & 4737.567 & $\pm \quad 1327.276$ & $4883.333=$ & \pm 1202.032 & $\begin{array}{c}- \\
0.358 \\
\end{array}$ & 0.722 & NS \\
\hline $\mathrm{HBg} / \mathrm{dl}$ & 10.686 & \pm 0.867 & 11.960 & \pm 0.379 & $5 . \overline{404}$ & 0.000 & HS \\
\hline Plat x $10^{9} / 1$ & 321.400 & $\pm \quad 34.307$ & 275.333 & \pm 44.820 & 3.829 & 0.000 & $\mathrm{HS}$ \\
\hline $\mathrm{T} \mathrm{IgE} \mathrm{Iu} / \mathrm{ml}$ & 199.200 & $\pm \quad 145.354$ & 62.267 & \pm 26.034 & 3.600 & 0.001 & $\mathrm{HS}$ \\
\hline
\end{tabular}

$\mathrm{P}$ value $>0.05$ is considered non-significant $(\mathrm{NS})$.

$\mathrm{P}$ value $\leq 0.05$ is considered significant $(\mathrm{S})$.

$\mathrm{P}$ value $\leq 0.01$ is considered highly significant ( HS ). 
Table (2): Comparison between atopic dermatitis children and control group as regard \% of expression and MFI of CD 38 and CXCR3 on CD3+ lymphocytes .

\begin{tabular}{|c|c|c|c|c|c|c|c|c|c|}
\hline \multirow{2}{*}{ Parameter } & \multicolumn{3}{|c|}{ AD Patient( $n$ ) 30} & \multicolumn{3}{|c|}{ Control (n) 15} & \multirow[b]{2}{*}{$\mathbf{t}$} & \multirow[b]{2}{*}{ P-value } & \multirow[t]{2}{*}{ Sig. } \\
\hline & Mean & \pm & SD & Mean & \pm & SD & & & \\
\hline $\mathrm{CD} 38 \%$ & 70.500 & \pm & 11.527 & 17.800 & \pm & 1.568 & 17.526 & $<0.001^{*}$ & HS \\
\hline MFI CD38 & 5.880 & \pm & 1.988 & 5.187 & \pm & 1.543 & 1.182 & 0.244 & NS \\
\hline CXCR3\% & 17.933 & \pm & 6.918 & 67.933 & \pm & 5.133 & -24.737 & $<0.001^{*}$ & HS \\
\hline MFI CXCR3 & 2.963 & \pm & 0.772 & 3.307 & \pm & 0.737 & -1.427 & 0.161 & NS \\
\hline
\end{tabular}

HS : High Significant .

NS : Non Significant ,

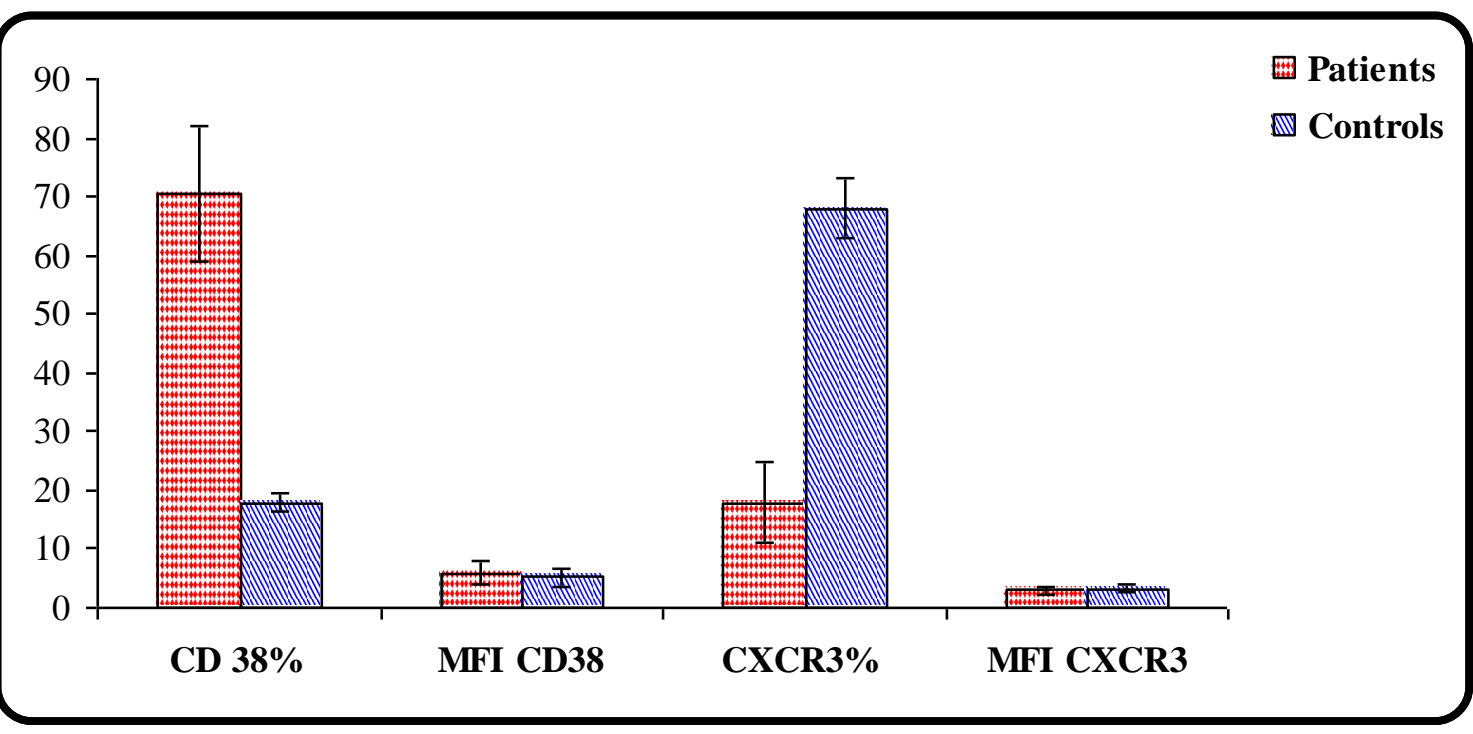

Figure (1) Comparison between \% of expression and MFI of CD38 and CXCR3 on CD3 + lymphocytes in AD patients and control group .

Table (3): Correlation between \% of expression of CD38 on CD3 + lymphocytes and all other studied parameters in AD children.

\begin{tabular}{|c|c|c|c|}
\hline Parameter & \multicolumn{2}{|c|}{ CD 38\% } & Significant \\
\hline & r & P-value & \\
\hline Age & -0.452 & 0.012 & HS \\
\hline TLC $\times 10^{9} / 1$ & 0.003 & 0.986 & \\
\hline Absolute eosinophil $\times 10^{9} / 1$ & 0.828 & 0.000 & HS \\
\hline Absolute lymphocytes $\times 10^{9} / 1$ & 0.060 & 0.754 & \\
\hline Absolute neutrophil $\times 10^{9} / 1$ & -0.258 & 0.169 & \\
\hline $\mathrm{Hb}$ g/dl & -0.050 & 0.799 & \\
\hline Platelets $\times 10^{9} / 1$ & 0.313 & 0.092 & \\
\hline $\mathrm{T} \mathrm{IgE} \mathrm{Iu/} \mathrm{ml}$ & 0.385 & 0.035 & HS \\
\hline CXCR3\% & -0.178 & 0.346 & \\
\hline
\end{tabular}

S : Significant .

HS: High Significant . 
Table (4): Correlation between \% of expression of CXCR3 on CD3 + lymphocytes and all other studied parameters in AD children .

\begin{tabular}{|c|c|c|}
\hline \multirow{2}{*}{ Parameter } & \multicolumn{2}{|c|}{ CXCR3\% } \\
\cline { 2 - 3 } & $\mathbf{r}$ & P-value \\
\hline Age & 0.162 & 0.391 \\
\hline TLC $\times 10^{9} / 1$ & -0.192 & 0.310 \\
\hline Absolute eosinophil $\times 10^{9} / 1$ & -0.080 & 0.675 \\
\hline Absolute lymphocytes $\times 10^{9} / 1$ & -0.174 & 0.358 \\
\hline Absolute neutrophil $\times 10^{9} / 1$ & -0.158 & 0.405 \\
\hline $\mathrm{Hb}$ g/dl & 0.293 & 0.123 \\
\hline Platelets $\times 10^{9} / 1$ & -0.114 & 0.549 \\
\hline $\mathrm{T} \mathrm{IgE} \mathrm{Iu/} \mathrm{ml}$ & -0.247 & 0.188 \\
\hline $\mathrm{CD} 38 \%$ & -0.178 & 0.346 \\
\hline
\end{tabular}

No significant correlation was found between the expression of CXCR3\% on CD3 + lymphocytes and all studied parameters in $\mathrm{AD}$ children .

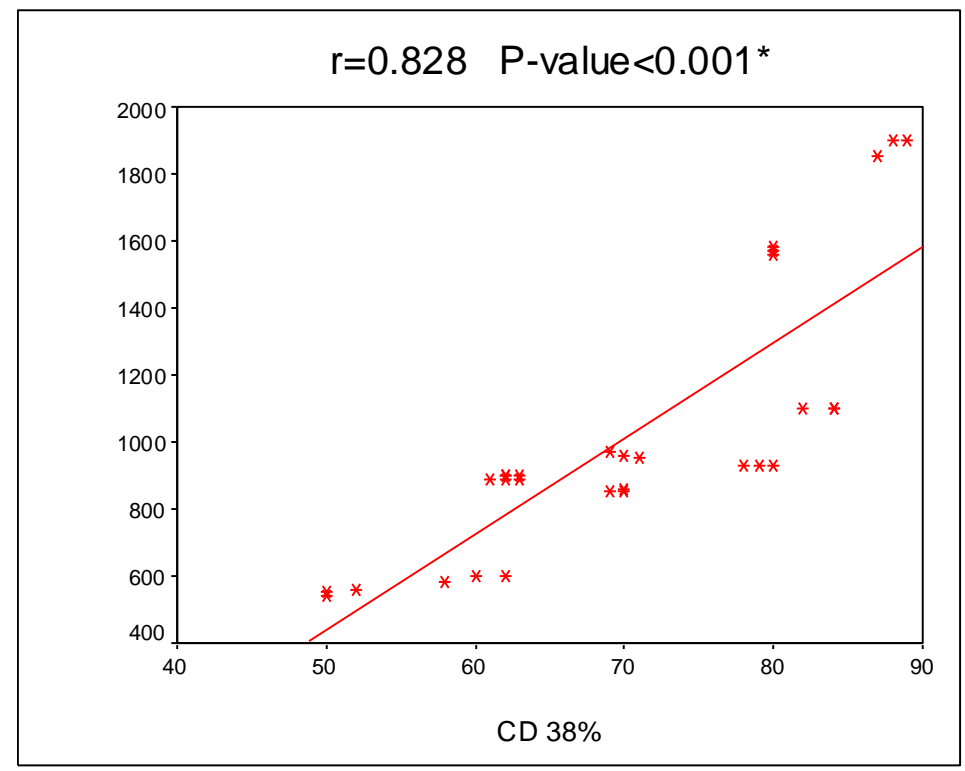

Figure (2) A highly significant positive correlation between CD38 \% and absolute eosinophil count in AD children. 
Expression of CD38 and CXCR3 in children.

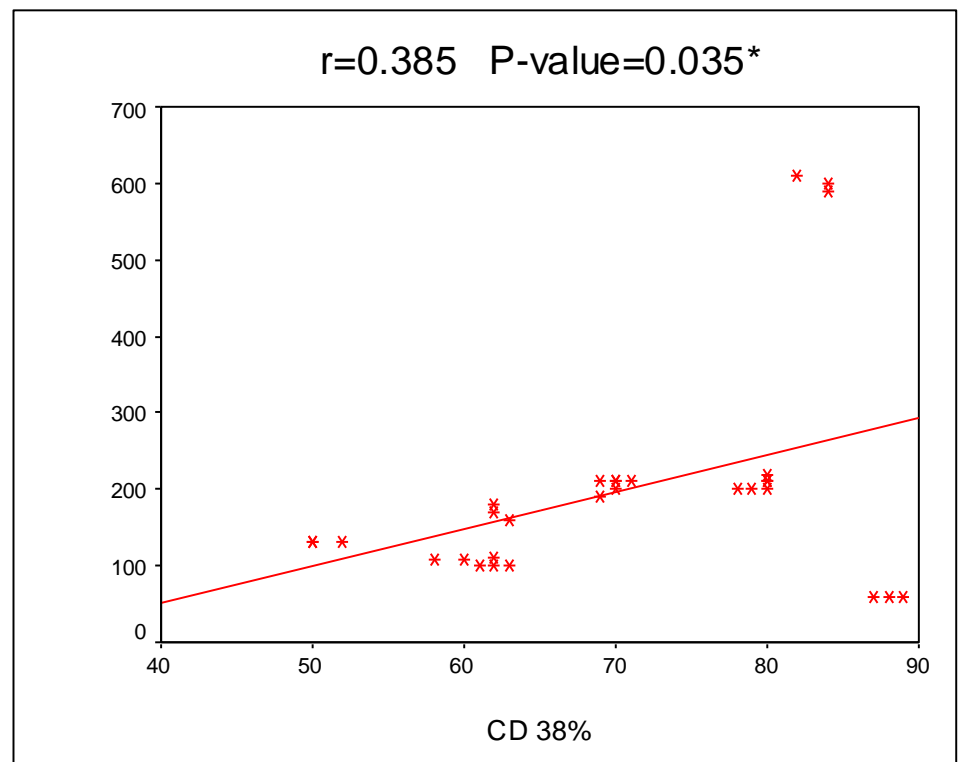

Figure (3) A significant positive correlation between CD $38 \%$ and total IgE level in AD children .

Table (5) Correlation between MFI of CD38 on CD3 + lymphocytes and all other studied parameters in AD children .

\begin{tabular}{|c|c|c|c|}
\hline \multirow{2}{*}{} & r & P-value & Significant \\
\cline { 2 - 4 } & -0.001 & 0.995 & \\
\hline Age & 0.237 & 0.208 & \\
\hline TLC $\times 10^{9} / 1$ & 0.442 & 0.014 & $\mathrm{~S}$ \\
\hline Absolute eosinophils $\times 10^{9} / 1$ & 0.244 & 0.194 & \\
\hline Absolute lymphocytes $\times 10^{9}$ & 0.147 & 0.438 & \\
\hline Absolute neutophils $\times 10^{9}$ & -0.021 & 0.913 & \\
\hline Hb g/d1 & 0.076 & 0.691 & \\
\hline PLT x10 & 0.002 & 0.992 & \\
\hline T IgE Iu/ ml & -0.193 & 0.307 & \\
\hline CXCR3 \% & &
\end{tabular}

S : Significant

Only a positive significant correlation between MFI of CD 38 on CD3 + lymphocyte and absolute eosinophil count was detected . 
Fawzia A. EL.Sheshtawy et al

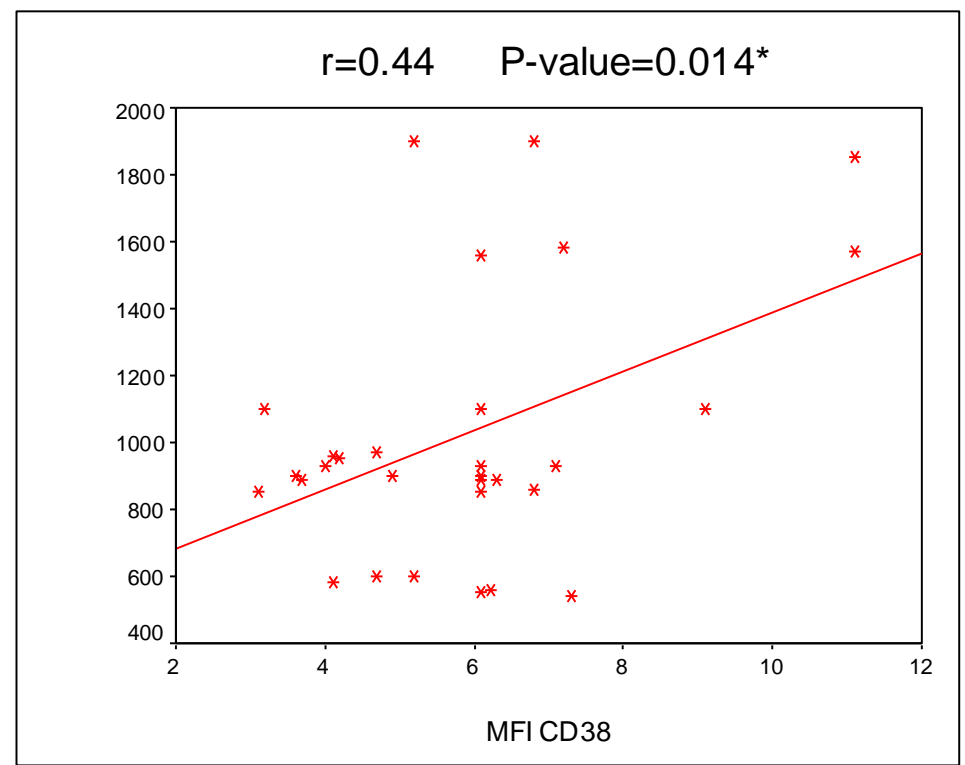

Figure ( 4 ) A significant positive correlation between MFI of CD 38 and absolute eosinophil count .

Table (6) Correlation between MFI of CXCR3 on CD3 + lymphocytes and all other studied parameters in AD children .

\begin{tabular}{|c|c|c|}
\hline \multirow{2}{*}{} & \multicolumn{2}{|c|}{ MFI CXCR3 } \\
\cline { 2 - 3 } & $\mathbf{r}$ & P-value \\
\hline Age & 0.164 & 0.385 \\
\hline TLC $\times 10^{9} / 1$ & -0.026 & 0.890 \\
\hline Absolute eosin. $\times 10^{9} / 1$ & -0.336 & 0.070 \\
\hline Absolute lymphocytes $\times 10^{9} / 1$ & 0.000 & 1.000 \\
\hline Absolute neutophils $\times 10^{9} / 1$ & 0.017 & 0.931 \\
\hline Hbg/dl & -0.024 & 0.903 \\
\hline PLT $\times 10^{9} / 1$ & -0.173 & 0.362 \\
\hline T IgE Iu/ $\mathrm{ml}$ & 0.120 & 0.528 \\
\hline CXCR3 $\%$ & 0.238 & 0.205 \\
\hline
\end{tabular}

No significant correlation between MFI of CXCR3 on CD3 + lymphocyte and all studied parameter was detected. 


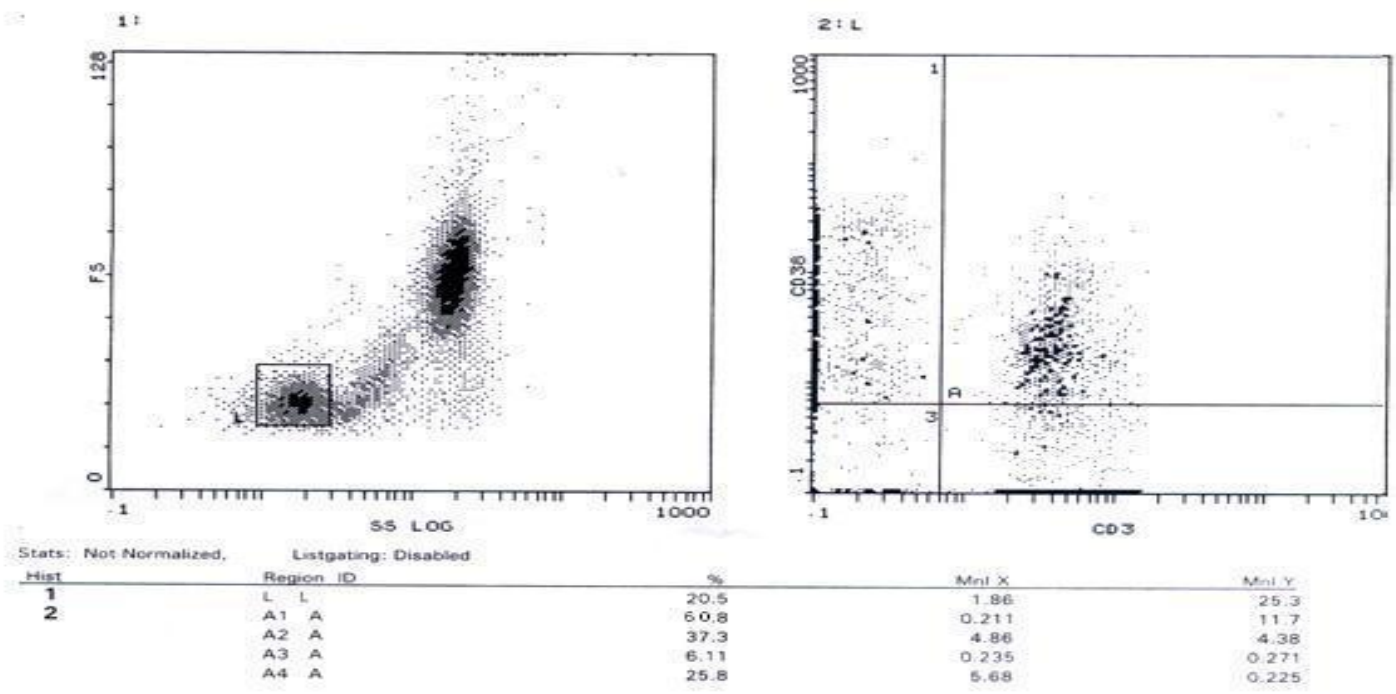

Figure (4) shows expression of CD38 \% on CD3+ lymphocyte in a patient with atopic dermatitis .

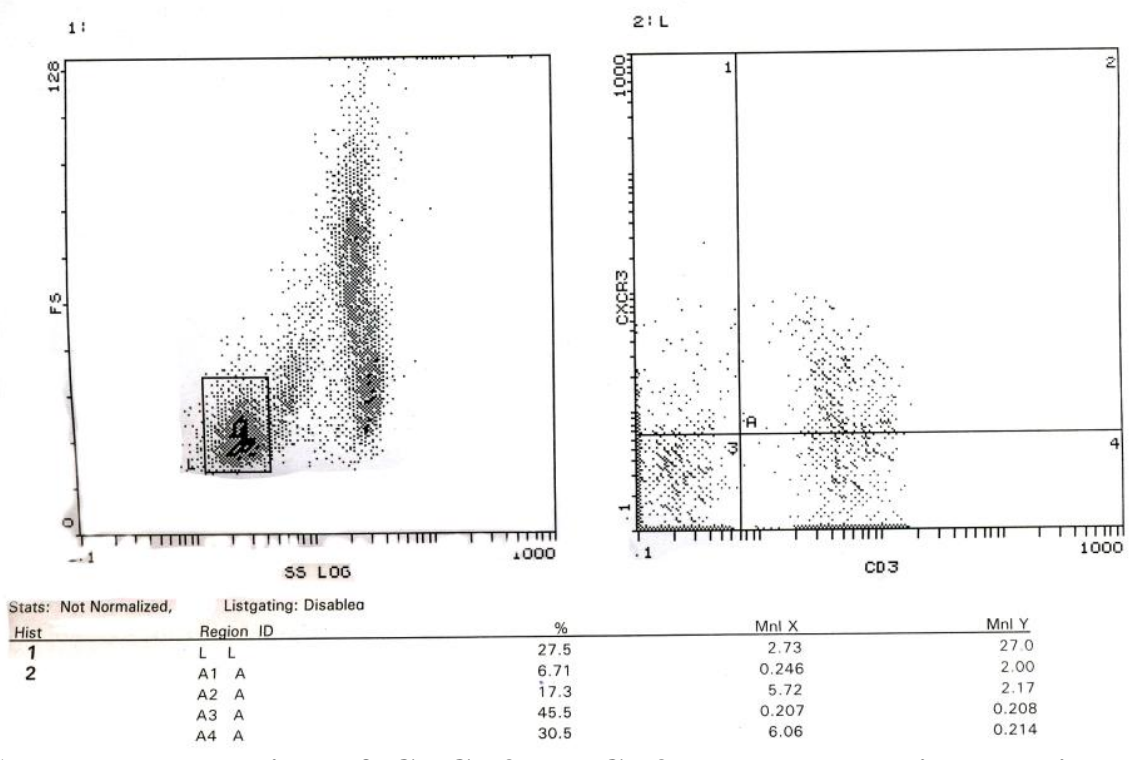

Figure (5) shows expression of CXCR3 on CD3+ lymphocyte in a patient with atopic dermatitis .

\section{Discussion}

Atopic dermatitis is a chronic or chronically relapsing inflammatory skin disease with a prevalence ranging from $10 \%$ to $20 \%$ in children and $1 \%$ to $3 \%$ in adults of developed countries. Skininfiltrating leukocytes play a pivotal role in the initiation and amplification of atopic skin inflammation. Recent studies demonstrated that infiltration of inflammatory cells into tissues is regulated by chemokines. $T$ helper cells are thought to play an important role in the pathogenesis of $\mathrm{AD}$. It is commonly believed that allergens activate Th2 cells, and it is likely that the cytokines produced by $\mathrm{Th} 2$ cells are crucial factors in the induction and maintenance of the disease (1).

Patients as well as the control group were studied for the $\%$ of expression and MFI of CD38, CXCR3 using flow cytometry . Serum level of $\operatorname{IgE}$, absolute eosinophil, absolute lymphocytes, absolute neutrophil were measured as well .

In the present study, the mean age of $\mathrm{AD}$ children was 6.5 years and this was in agreement with Hanifin and Rajka 1980 
(22 ) . Manal \& Lamia 2007 reported a mean age of 7.9 years in a similar study .

The present results revealed that the absolue blood eosinophil count in $\mathrm{AD}$ children were significantly higher than in control children. Also in this study there was a significant increase in the total serum IgE level in $\mathrm{AD}$ children than the control . These results may be due to the enhanced production of Th2; IL-4 and IL-5.

Elevated serum IgE level and blood eosinophilia have been encountered in most of $\mathrm{AD}$ patients, possibly as a result of the enhanced production of Th2- type cytokines; IL-4 and IL-5. IL-4 has been shown to stimulate B lymphocytes to produce IgE whereas IL-5 has been known to control growth ,differentiation and activation of eosinophils $(10,11)$.

Serum IgE levels have been found to be significantly higher in $\mathrm{AD}$ children than in normal controls. Several studies have reported a direct correlation between serum IgE levels and disease activity $(12,13,14)$, while others did not find such correlation $(15,16)$.

This study showed a significant increase of platelets count in $\mathrm{AD}$ patients compared to control group which indicate chronic inflammation, present in patients with $\mathrm{AD}$ may cause an increased platelet count.

Increase platelet is usually mediated by increased release of a number of cytokines in response to infections and inflammation. Thrombopoietin (TPO), the primary cytokine for platelet production and maturation, and interleukin (IL)-6, are usually initially elevated in response to the primary events mentioned earlier, and they stimulate an increase in platelet production (26).

The results of this study show a significant decrease in $\mathrm{Hb}$ level in $\mathrm{AD}$ patient when compared to control . These decrease of $\mathrm{Hb}$ may be due to anemia of chronic disease .The released cytokines which could suppress erythropoiesis may play a role.

Reticuloendothelial cells retain iron from senescent RBCs, making iron unavailable for $\mathrm{Hb}$ synthesis. There is thus a failure to compensate for the anemia with increased RBC production. Macrophagederived cytokines (eg, IL-1 $\beta$, tumor necrosis factor- $\alpha$, interferon- $\beta$ ) in patients with infections, inflammatory states, and cancer cause or contribute to the decrease in EPO production and the impaired iron metabolism (25).

The results of this study showed increase in the \% of expression of CD38 molecules on $\mathrm{CD} 3+\mathrm{T}$ lymphocytes of $\mathrm{AD}$ children compared to healthy control ( $\mathrm{p}<$ $0.001)$. No significance difference between MFI of CD38 in AD children and control group. The CD $38 \%$ had a significant correlation with both absolute eosinophil count and total serum $\operatorname{IgE}$. While the MFI of CD38 had significant correlation with absolute eosinophil count only. These results indicated increased expression of the activation marker $\mathrm{CD} 38$ on peripheral blood CD3 lymphocyte in $\mathrm{AD}$ children .

In atopic dermatitis increase in production of serum $\operatorname{IgE}$, absolute eosinophil and activation marker result from Th2 dominance. The Th2 -cytokine IL-4 is necessary for IgE (17). Additionally IL-4 inhibits the generation of Th1-cells.

In individuals with atopic disease, CD3+ $\mathrm{T}$ cells express high levels of activation markers such as, CD38 and CD71, which is compatible with the transition from naive to antigen-experienced status and their role in the recognition of skin-associated antigens and contribution to cutaneous inflammation (17).

CXC chemokine receptor 3 (CXCR3) is selectively expressed on T helper 1 (Th1) type $\mathrm{T}$ cells and has been shown to be responsible for Th1-dominant immune responses (18).

In this study, analysis of the Percent of expression and MFI of CXCR3 on peripheral blood $\mathrm{T}$ lymphocytes of patients with AD was don by using antihuman CXCR3 monoclonal antibody. A highly significant lower expression of CXCR3 \% was found on peripheral blood CD3+ $\mathrm{T}$ lymphocytes of $\mathrm{AD}$ patients than healthy control $(\mathrm{p}<0.001)$. The MFI of CXCR3 revealed no statistical difference. Also no significant correlation between \% and MFI of CXCR3 and all other studied parameter could be detected.

CXCR3 has been suggested as being associated with Th1 phenotype (18) and with antigen-experience and effector differentiation in Th1 cells. Reduced levels 
of expression CXCR3 on CD3+ $\mathrm{T}$ cells from $\mathrm{AD}$ patients thus are in keeping with the Th2-type cytokine profiles in these patients(19).

The results were in agreement with other studies reporting equal decreased percentage of CXCR3 on CD3 + lymphocytes in patients with atopic dermatitis compared to healthy controls (19-20-21).

In summary, compared the phenotypic CD38 and chemokine-CXCR3 on CD3 + T cells in $\mathrm{AD}$ children and non-atopic healthy controls. $\mathrm{CD}+3 \mathrm{~T}$ cells from $\mathrm{AD}$ patients had increased expression of marker of activation CD38 \%. Whereas CXCR3 \%expression on $\mathrm{CD} 3+$ lymphocytes decreased in $\mathrm{AD}$ than normal control .Also these results may suggest the dysbalance between Th1/Th2 in AD patients. The peripheral blood $\mathrm{T}$ - lymphocytes in $\mathrm{AD}$ children showed increased \% of expression of the activation marker CD38. The increased expression of $\mathrm{CD} 38$ was positively correlated with absolute eosinophil count and total serum IgE. On the other hand \% of expression of CXCR3 was reduced on $\mathrm{T}$ - lymphocytes of $\mathrm{AD}$ children . The results may indicate the involvement of many $\mathrm{T}$ - cell subsets in the assay .

\section{Reference}

1. Sehra S, Tuana FM, Holbreich $M$ (2008): Scratching the surface: towards understanding the pathogenesis of atopic dermatitis. Crit Rev Immunol, 28:15-43.

2. Seneviratne SL, Jones L, King AS (2002): Allergen-specific CD8(+) T cells and atopic disease. J Clin Invest ,110: 1283-91.

3. Neumann C, Gutgesell C, Fliegert F, Bonifer R, Herrmann F (1996): Comparative analysis of the frequency of house dust mite specific and nonspecific Th1 and Th2 cells in skin lesions and peripheral blood of patients with atopic dermatitis ., J Mol Med .,74 : 401-6.

4. Berthelier V , Tixier JM, Muller-Steffner H, Schuber F, Deterre P ( 1998 ): Human CD38 is an authentic NAD (P) + glycohydrolase. Biochem J.,330:1383-90.

5. Deaglio $S$,Mallone $R$ Baj $G$ (2000): CD38/CD31, a receptor/ligand system ruling adhesion and signalling in human leukocytes. Chem Immunol.,75:99-102.

6. Morra M, Zubiaur M, Terhorst C, Sancho J, Malavasi F ( 1998 ) : CD38 is functionally dependent on the TCR/CD3 complex in human $\mathrm{T}$ cells. FASEB J., 12:581-92.

7. Clark-Lewis I, Mattioli I, Gong JH, Loetscher P (2003): "Structure-function relationship between the human chemokine receptor CXCR3 and its ligands". J. Biol. Chem.,278 (1): 289-95.

8. Lasagni L, Francalanci M, Annunziato F, Lazzeri E, Giannini S, Cosmi L, Sagrinati C, Mazzinghi B, Orlando C, Maggi E, Marra F, Romagnani S, Serio $M$, Romagnani P (2003): "An alternatively spliced variant of CXCR3 mediates the inhibition of endothelial cell growth induced by IP-10, Mig, and I-TAC, and acts as functional receptor for platelet factor 4". J. Exp. Med., 197 (11): 1537-49

9. Qin S, Rottman JB, Myers P, Kassam N, Weinblatt M, Loetscher M, Koch AE, Moser B, Mackay CR (1998): "The chemokine receptors CXCR3 and CCR5 mark subsets of $\mathrm{T}$ cells associated with certain inflammatory reactions". J. Clin. Invest., 101 (4): 746-54.

10. Abramovits W (2005): Atopic dermatitis. J Am Acad Dermatol., 53: 586 -593 .

11. Yamamoto N, Sugiura H, Tanaka $K$ and Uehara M (2003): Heterogeneity of interleukin 5 genetic background in atopic dermatitis patients: significant difference between those with blood eosinophilia and normal eosinophil levels. J Dermatol Sci.,33: 121126 .

12. Aral M, Arican O, Gul M (2006): The relationship between serum levels of total IgE, IL-18, IL-12, IFN- $\gamma$ and disease severity in children with atopic dermatitis. Mediators Inflamm, 2006: 4 : 73-98.

13. Dhar S, Malakar R, Chattopadhyay S. (2005): Correlation of the severity of atopic dermatitis with absolute counts in peripheral blood and serum IgE levels. Indian $\mathrm{J}$ Dermatol Venereol Leprol., 71: 246-249.

14. Ahmed $I$ and Nasreen $S$ (2007): Frequency of raised serum IgE level in childhood atopic dermatitis. J Pak Med Assoc., 57: 431-434 .

15. Leonardi S, Rotolo N, Vitaliti G. (2007).: $\mathrm{IgE}$ values and T-lymphocyte subsets in children with atopic eczema / dermatitis syndrome. Allergy Asthma Proc ., 28: 529 534.

16. Rothe MJ and Grant-Kels JM (1996): Atopic dermatitis: an update. J Am Acad Dermatol , 35: 1-13.

17. Akdis M , Trautmann A, Klunker S, (2003): $\mathbf{T}$ helper (Th) 2 predominance in atopic diseases is due to preferential apoptosis of circulating memory/effector Th1 cells. FASEB J ., (10 ) : 26-35. 
18. Elsner J, Escher SE, Forssmann U. (2004): Chemokine receptor antagonists: a novel therapeutic approach in allergic diseases. Allergy .,(59):1243-58.

19. Hatano $\mathbf{Y}$, Katagiri $\mathbf{K}$, Takayasu $\mathbf{S}$ (2001): Decreased levels of CXCR3 transcripts in peripheral blood mononuclear cells from patients with atopic dermatitis and with cutaneous diseases associated with eosino-philia. Arch Dermatol Res.,293:319322.

20. Okazaki H, Kakurai M, Hirata D, Sato H, Kamimura T, Onai N, Matsushima K, Nakagawa H, Kano S, Minota S (2002 ): Characterization of chemokine receptor expression and cytokine production in circulating CD4+ $\mathrm{T}$ cells from patients with atopic dermatitis: up-regulation of $\mathrm{C}-\mathrm{C}$ chemokine receptor 4 in atopic dermatitis. Clin Exp Allergy.,32:1236-1242.

21. Wakugawa M, Nakamura K, Kakinuma T, Onai N, Matsushima K, Tamaki K (2001): CC chemokine receptor 4 expression on peripheral blood CD4+ $\mathrm{T}$ cells reflects disease activity of atopic dermatitis. J Invest Dermatol ., 117:188$196 .$.

22. Hanifin JM, Rajka G ( 1980 ): Diagnostic features for atopic dermatitis. Acta Dermatol venerol, 92: 744-747.

23. Barakat T and Lamia H (2007 ): Blood Eosinophil Levels and Serum Levels of Total IgE and Thrombospondin-1 in Atopic Dermatitis Children. Derma.,18 (3) : 9-16.

24. Farrell AM, Antrobus P, Simpson D, (2001): A rapid flow cytometric assay to detect CD4+ and CD8+ T-helper (Th) 0, Th1 and Th2 cells in whole blood and its application to study cytokine levels in atopic dermatitis before and after cyclosporin therapy. Br J Dermatol., 144: 24-33.

25. Sihler K. C and Napolitano LM. (2008).: Anemia of Inflammation in Critically Ill Patients. J Intensive Care Med., 23: 295302.

26. Dame C and Sutor AH (2005): Primary and secondary thrombocytosis in childhood. Br J Haematol., 129 (2) : 165-77. 


\section{ظهور سي دي 38 و سي إكس سي ار 3 في حالات التهاب الجلا الحساس في الأطفال}

\section{فوزية عبد السميع الششتاوي ـ نجلاء عبد الله احمد ـ منال عبدالسلام

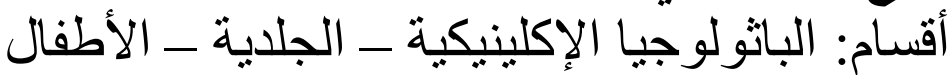

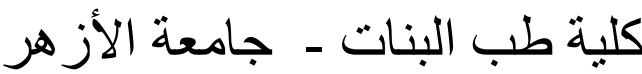

يعتبر التهاب الجلد الحساس من الأمر اض الجلدية المزمنة ويتراوح انتشاره من 10 \% الى 20\% في اطفال البلدان المتطورة ـ كما أن خلايا الدم البيضاءتلعب دورا النئ في تلقين

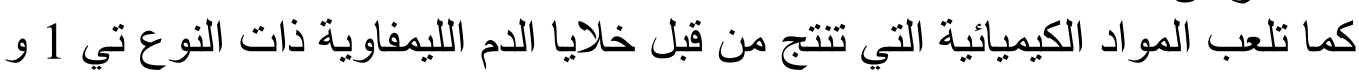

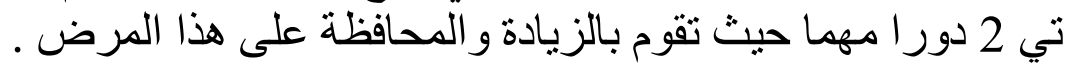

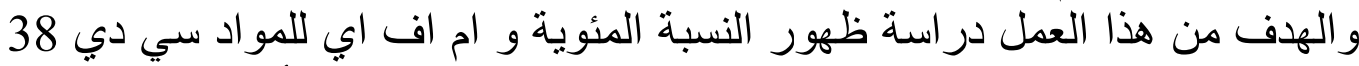

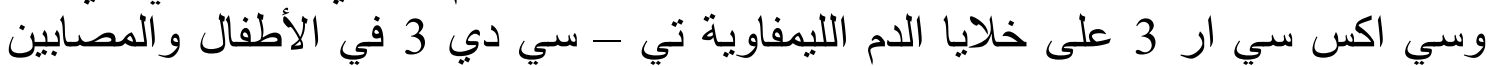

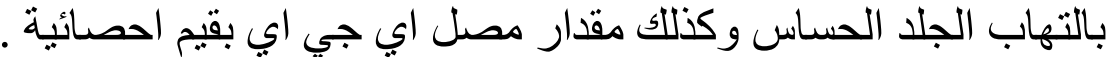

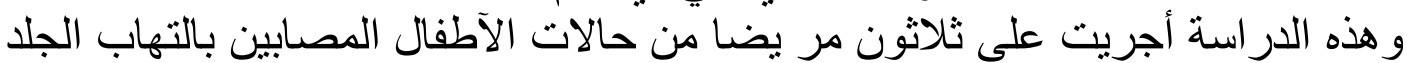

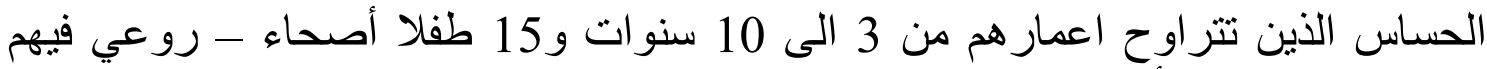

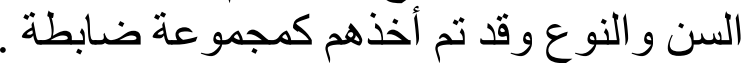

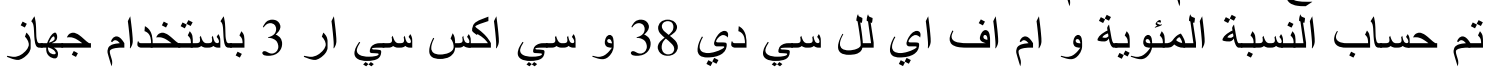

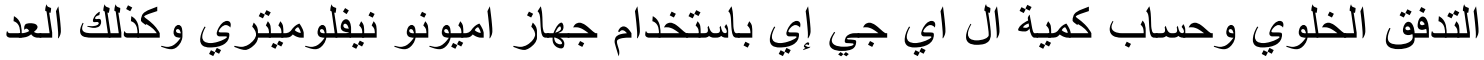
النو عي لخلاياً الدم البيضاء النياء فكان منوسط النسبة المئوية من سي دي 38 النياء 38 على سي دي 3 للخلايا الليمفاوية تي و إم إف أبي

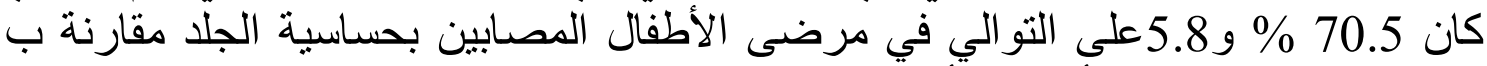
17.8\% و 5.1 \% \% \% و 5.8 في الأطفال الأصحاء

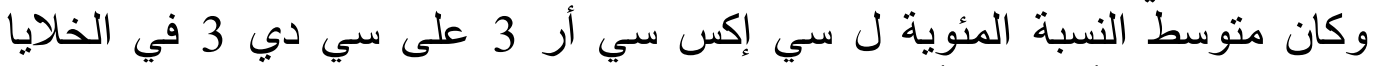

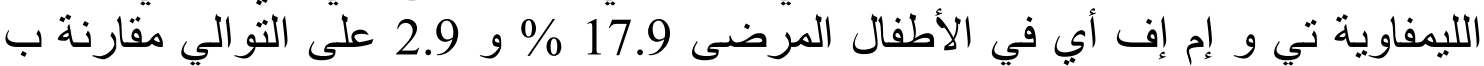

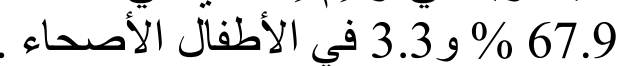
ومتوسط المصل ألكلي أبي جي إي في المرضى 199.3 مقارنة ب 62.27 في الأطفال الأصحاء. وبهذه النتائج نجد أن هناك ارتباط بين زيادة نسبة سي دي 38 على الخلايا الليمفاوية

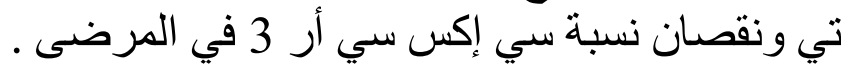

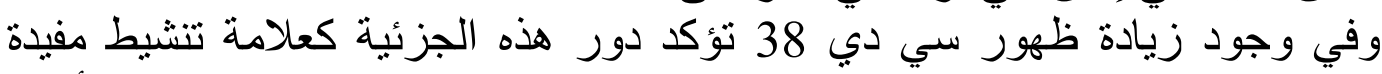

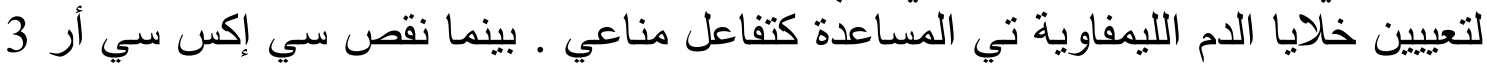

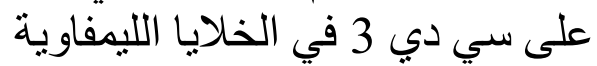

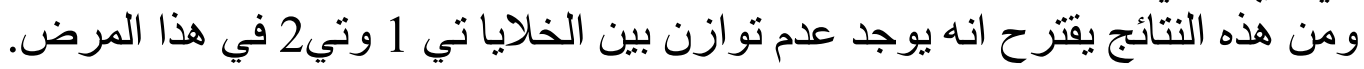

